\title{
Labramia ambondrombeensis (Sapotaceae), a Critically Endangered new species from Madagascar.
}

\author{
Aina Randriarisoa, Yamama Naciri \& Laurent Gautier
}

\begin{abstract}
RANDRIARISOA, A., Y. NACIRI \& L. GAUTIER (2020). Labramia ambondrombeensis (Sapotaceae), a Critically Endangered new species from Madagascar. Candollea 75: 83-87. In English, English and French abstracts. DOI: http://dx.doi.org/10.15553/c2020v751a8

Timber of the family Sapotaceae are appreciated for their physical properties internationally as well as locally, which often put a serious pressure on species survival. Taxonomic efforts are badly needed before producing reliable conservation assessments for the Malagasy species. In the framework of the revision of three related Sapotaceae genera, all endemic from Madagascar and surrounding islands of the Western Indian Ocean, a new species of Labramia A. DC. has been identified. It is described and illustrated here. Labramia ambondrombeensis L. Gaut. \& Randriarisoa is one of the two Labramia species that have relatively small leaves. It is compared to Labramia platanoides Capuron ex Aubrév., the other small-leaved species from which it differs in leaf shape, pedicel size and ovary cell number. Labramia ambondrombeensis is known from a single collection that comes from a littoral forest in the Northeastern coast of the island, lacking any legal protection and is preliminary assessed as "Critically Endangered" using the IUCN Red List Criteria.
\end{abstract}

\section{Résumé}

RANDRIARISOA, A., Y. NACIRI \& L. GAUTIER (2020). Labramia ambondrombeensis (Sapotaceae), une nouvelle espèce en danger critique d'extinction de Madagascar. Candollea 75: 83-87. En anglais, résumés anglais et français. DOI: http://dx.doi.org/10.15553/c2020v751a8

Le bois de la famille des Sapotaceae est apprécié pour ses propriétés mécaniques, dans le commerce international comme à l'échelon local, ce qui met en danger la survie des espèces de cette famille. Un important travail taxonomique est nécessaire avant de pouvoir produire des évaluations de menaces fiables pour les espèces malgaches. Dans le cadre de la révision taxonomique de trois genres endémiques de Madagascar et des îles périphériques, une nouvelle espèce de Labramia $\mathrm{A}$. DC. a été identifiée. Elle est décrite et illustrée ici: Labramia ambondrombeensis L. Gaut. \& Randriarisoa. C'est l'une des rares espèces de Labramia qui aient des feuilles relativement petites. Elle est comparée à Labramia platanoides Capuron ex Aubrév., qui est l'autre espèce à petites feuilles et qui diffère par la forme de ces dernières, la taille des pédicelles et le nombre de loges des ovaires. Labramia ambondrombeensis n'est connue que d'un seul spécimen qui provient d'une forêt littorale de la côte nord-est de l'île ne faisant l'objet d'aucune protection. Elle est préliminairement assignée à la catégorie "En danger critique d'extinction" selon les Critères de la Liste Rouge de l'UICN.

\section{Keywords}

SAPOTACEAE - Labramia - Madagascar - New species - Taxonomy - IUCN Red List

\footnotetext{
Address of the authors:

Conservatoire et Jardin botaniques de la Ville de Genève and Laboratoire de botanique systématique et biodiversité de l’Université de Genève, C.P. 71, 1292 Chambésy, Switzerland. E-mail: laurent.gautier@ville-ge.ch
} 


\section{Introduction}

Sapotaceae is a well-defined tropical plant family of about 1250 species (Pennington, 1991; Govaerts et al., 2001). Its members are mostly large trees that are highly valued for their mechanical properties and widely used in construction. Following the rosewood crisis (HAssolD et al., 2016), they are, along with Ebenaceae, the next group likely to be severely affected by illegal logging in protected areas. Almost all species are characterized by a slow growth and long generation times and can be considered, from a conservation point of view, as markers of primary forests. However, classification based on morphological data is highly controversial in this family, and generic delimitations have always been a matter of debate (e.g. LAM, 1939; Aubréville, 1964; Baehni, 1965; Pennington, 1991): depending on the weight given to one or the other character, classification and number of accepted genera can change drastically. Those discrepancies do not allow conservation action to rely on strong taxonomic data. Thanks to molecular studies (e.g. Anderberg \& Swenson, 2003; Swenson \& Anderberg, 2005), nomenclatural stability is at hand and current efforts aim at revising this economically important and threatened family worldwide. In the Flore de Madagascar et des Comores (Aubréville, 1974), the Sapotaceae family was represented by 11 genera and 84 species. The abundant material accumulated since clearly indicates the need of re-evaluating the taxonomy of this family for Madagascar, with the help of appropriate molecular methods. Numerous new taxa are suspected, some of them having been already described (e. g. Gautier et al., 2013; Mackinder et al., 2016; Gautier \& Naciri, 2018).

The Sapotaceae genera present in Madagascar belong to the two main subfamilies: Chrysophylloideae (with the genera Donella Pierre ex Baill. and Gambeya Pierre), but mainly to Sapotoideae. Within Sapotoideae, three tribes are represented: Sideroxyleae (with Sideroxylon L.), the recently described endemic Tsebonae (GAutier et al., 2013) (with Bemangidia L. Gaut., Capurodendron Aubrév., and Tsebona Capuron) and Sapoteae (with Mimusops L., Faucherea Lecomte, Labourdonnaisia Bojer, Labramia A. DC., and Manilkara Adans.). The four latter genera belong to the subtribe Manilkarineae (Pennington, 1991) which is characterized by a calix arranged in two whorls of three sepals. A recent molecular study on the genus Manilkara worldwide (Armstrong, 2010) including a restricted sample of Faucherea, Labourdonnaisia and Labramia pointed out that the relationships between these three genera are not well-resolved. As currently accepted, Faucherea is endemic to Madagascar, Labourdonnaisia being shared with the Mascarene Islands, and Labramia with the Comoros. Aiming at establishing conservation action based on strong taxonomic data, we undertook molecular studies and in-depth morphological analyses on a large sample of Faucherea, Labourdonnaisia and Labramia species, to investigate the generic circumscriptions and to solve species delimitations within this group. The three genera have many features in common. However, Labramia clearly differs by the presence of a pair of dorsal appendages to the corolla lobes, a glabrous ovary, and seeds with a lateral scar almost as long as the seed. It is considered by Pennington (1991) as a "well-knit group of [...] species". Moreover, it appears as a well-supported monophyletic clade according to previous molecular study (Armstrong, 2010). Our analyses based on an extended sampling and numerous nuclear genes give congruent results (Randriarisoa et al., unpubl. data).

There are currently nine known species of Labramia, among which eight are endemic to Madagascar (Gautier, 2003) and one to the Comoros (Labat \& Pascal, 1997). In Madagascar, the geographical distribution of the genus extends mainly along the dense humid evergreen forest of the Eastern Domain (Humbert, 1955), but with one species found in the karstic limestone massifs in the West and the North. While revising the herbarium specimens of all Labramia species, many specimens could not be identified with confidence using the treatment of Aubréville (1974). Among the material sorted as potential new species to be described, it was obvious that a Labramia collection from the littoral forest in the Northeastern coast clearly differed from all other specimens. Taking into account its rarity, the fragility of the habitat of its single known location (Consiglio et al., 2006), and its clear morphological differences from other Labramia species, we propose here its formal description, anticipating the results of ongoing molecular studies which will ultimately provide a complete taxonomic revision of the genus. The new species is provided with a line drawing and its risk of extinction assessment using the IUCN Red List Categories and Criteria (IUCN, 2012).

\section{Taxonomy}

Labramia ambondrombeensis L. Gaut. \& Randriarisoa, sp. nov. (Fig. 1).

Holotypus: Madagascar. Reg. SAVA [Prov. Antsiranana]: Fiv. Vohemara, Fkt. Manakana, à l'E du village à Ambondrobe, $13^{\circ} 43^{\prime} 08^{\prime \prime} \mathrm{S} 50^{\circ} 05^{\prime} 50 " \mathrm{E}$, 13.III.2004, Al., Razakamalala, Rabevohitra \& Faralaby 1077 (G [G00105531]!; iso-: MO-1979356!, P [P04568848]!, TEF!).

Labramia ambondrombeensis L. Gaut. \& Randriarisoa is similar to L. platanoides Capuron ex Aubrév. in having relatively small leaves for the genus but differs by its cuneiform leaf blade (vs. obovate), by its longer flower pedicels (12-15 vs. 6-7 mm) and its 9-10 celled ovary (vs. 6(-7) celled).

Tree (dimensions unknown), with white latex. Ultimate twigs $2 \mathrm{~mm}$ diameter, glabrous, brownish, with pales lenticels, soon becoming greyish and longitudinally ridged. Leaves 

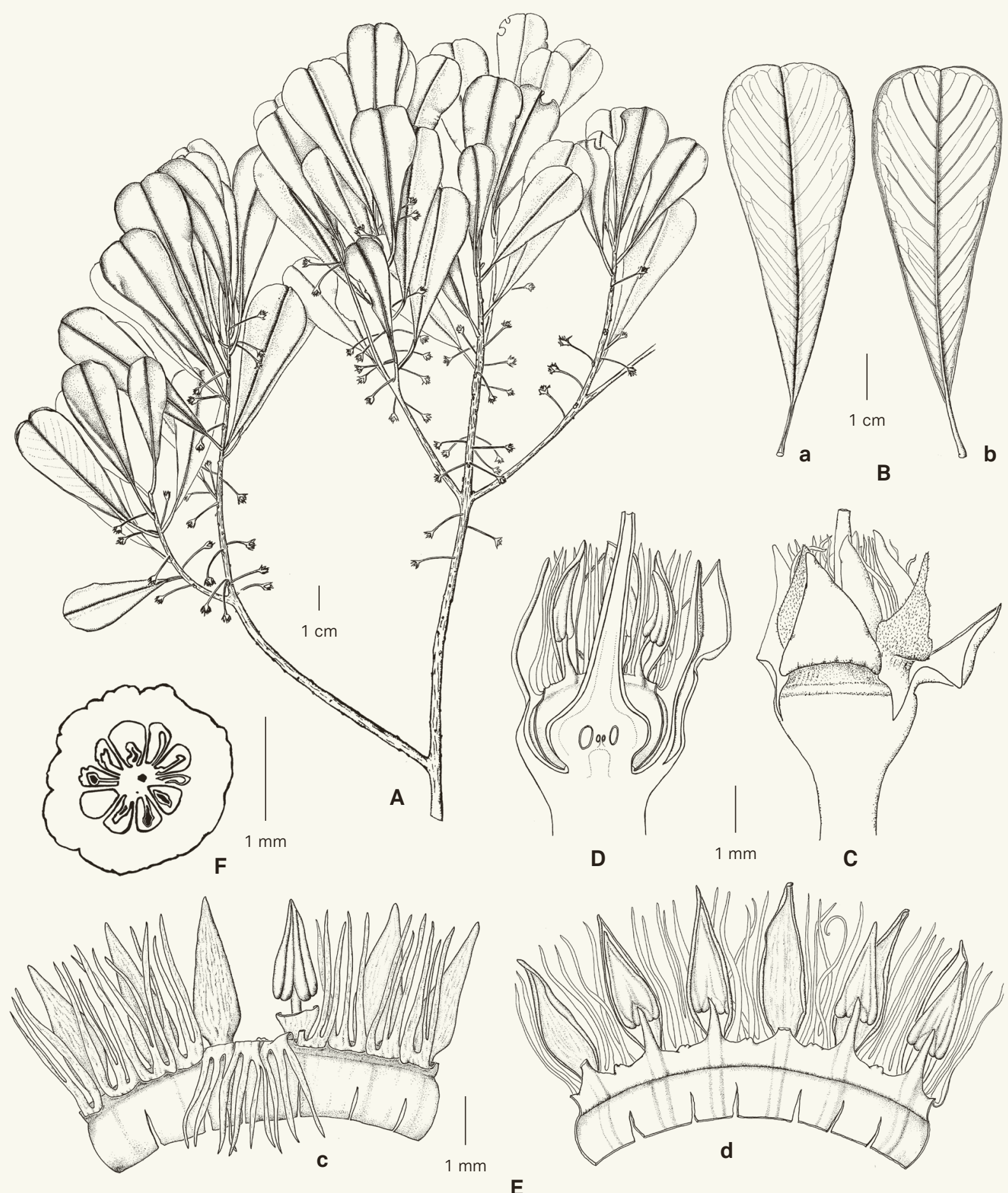

E

Fig. 1. - Labramia ambondrombeensis L. Gaut. \& Randriarisoa. A. Flowering branch; B. Leaf with venation details (a: upper side; b: lower side); C. Flower; D. Flower in longitudinal section; E. Detached corolla spread opened (c: outer side, with appendages folded down and one lobe removed to show one lobe and one stamen; d: inner side, with two stamens removed to show inner side of lobes); $F$. Transversal section of the ovary. [Razakamalala et al. 1077, G] [Drawing: G. Loza] 
alternate, petiole $10-15 \times 1.1-1.6 \mathrm{~mm}$, glabrous, with a median groove on upper side in continuation of the primary nerve; blade cuneiform, the widest portion 1/4 from the top and decreasing almost regularly to the acute base, apex rounded to slightly emarginated; (30-)40-65(-70) × 15-30 mm, entirely glabrous even when young, drying brown and discolours, darker above. Primary nerve prominent below, depressed above; secondary venation inconspicuous on upper side, visible on lower side, 10-12 pairs of secondaries, ascending with an angle of c. $30^{\circ}-40^{\circ}$, straight and parallel to each other until their connexion through a marginal nerve $0.9 \mathrm{~mm}$ from the margin; intersecondaries present; tertiary venation faint. Flowers 1-3, fasciculate, borne axillary to the current year's leaves or above the scar of previous year's fallen leaves; flowering pedicels $12-15 \times 0.6-0.8 \mathrm{~mm}$, broadening to c. $1.2 \mathrm{~mm}$ in their upper third, entirely glabrous. Sepals 6, arranged in two valvate whorls; the three outer ones ovate, $4.5 \times 2.0 \mathrm{~mm}$, apex acute, base rounded, entirely glabrous, the three inner ones lanceolate, $4.5 \times 1.5 \mathrm{~mm}$, apex acute, base rounded, thinly puberulent on outer side, inner side glabrous. Corolla gamopetalous glabrous, tube $2.2 \mathrm{~mm}$ long, with a spherical lower part $1.2 \mathrm{~mm}$ long and $1.4 \mathrm{~mm}$ in diameter surrounding the ovary, then constricted to $1.0 \mathrm{~mm}$ in diameter, the upper part thicker and broadening up to the mouth, with 6 lanceolate lobes, $3.4 \times 1.0 \mathrm{~mm}$, apparently erect at anthesis, each with a pair of lateral appendages deeply incised in linear filaments up to $2.7 \mathrm{~mm}$ long. Stamens 6 , filaments $0.4 \mathrm{~mm}$ broad at base, tapering to $0.2 \mathrm{~mm}$ at top, $0.8 \mathrm{~mm}$ long, attached to the top of the corolla tube. Anther pairs narrowly sagittate, medifixed, extrorse, $2.2 \times 0.8 \mathrm{~mm}$ at the broadest, concealed in the corolla lobes. Staminodes absent or if present then 6, vestigial, alternate with respect to petals and stamens, triangular, $0.5 \times 0.5 \mathrm{~mm}$, glabrous. Ovary broadly conical, $2.2 \mathrm{~mm}$ high $\times 1.2 \mathrm{~mm}$ in diam., glabrous, 9-10 celled with 1 ovule per cell, style narrowly conical $4 \mathrm{~mm}$ long, $1.3 \mathrm{~mm}$ diam. at base, $0.4 \mathrm{~mm}$ below stigma, glabrous. Fruit unknown.

Etymology. - This species epithet refers to the name of the village of Ambondrombe, near the littoral forest where the type specimen was collected.

Phenology. - The flowering specimen was collected in March.

Distribution and Ecology. - Labramia ambondrombeensis is only known from the type collection in Northeastern Madagascar, at the extreme North of the Eastern Phytogeographic Domain, near the southern limit of the Northern Sector of the Western Domain (Humbert, 1955). It was collected in a littoral forest on sands.
Conservation status. - The new species is known only from a single location in a little patch of unprotected littoral forest. Littoral forest is under major threat of logging and habitat conversion (Consiglio et al., 2006). With only one known location and an $\mathrm{AOO}$ of $4 \mathrm{~km}^{2}$, outside of the protected area network, L. ambondrombeensis is assigned a provisional status of "Critically Endangered" [CR B1ab(i,ii,iii)+2ab(i,ii,iii)] using the IUCN Red List Criteria (IUCN, 2012).

Notes. - Labramia ambondrombeensis is clearly distinct from most other Labramia species because of its small leaves (4.0-6.5 cm long). The only other species, also occurring in the North of Madagascar, with such small leaves is L. platanoides Capuron ex Aubrév. Apart from the morphological distinctions, habitat preferences distinguish the two species: while the specimen of Labramia ambondrombeensis was collected in littoral forest on sand, Labramia platanoides is known to have a predilection for dry deciduous to semi-deciduous forests on limestone (Aubréville, 1974). Labramia ambondrombeensis is not the only species in littoral forest; further south, under per-humid climate, one finds $L$. bojeri with much larger leaves (up to $25 \mathrm{~cm}$ long).

\section{Acknowledgments}

The authors would like to thank Gabriella Loza for her nice drawing of the new species and the P, MO and TEF herbaria for providing loans and/or information. AR is funded by the Bourses d'excellence de la Confédération suisse pour chercheurs étrangers. The project Understanding Madagascar Sapotaceae is funded by the Franklinia foundation. We would like also to thank Martin Callmander and Lorenzo Ramella for comments and suggestions.

\section{References}

Anderberg, A.A. \& U. Swenson (2003). Evolutionary lineages in Sapotaceae (Ericales): a cladistic analysis based on $\mathrm{NdhF}$ sequence data. Int. J. Pl. Sci. 164: 763-773. DOI: https://dx.doi. org $/ 10.1086 / 376818$

Armstrong, K.E. (2010). Systematics E biogeography of the pantropical genus Manilkara (Sapotaceae). PhD thesis, University of Edinburgh.

Aubréville, A. (1964). Les Sapotacées: taxonomie et phytogéographie. Adansonia, Mém.1.

Aubréville, A. (1974). Sapotaceae. In: Humbert, H. (ed.), Fl. Madagascar Comores 164.

Baenni, C. (1965). Mémoires sur les Sapotacées 3. Inventaire des Genres. Boissiera 11. 
Consiglio, T., G.E. Schatz, G. McPherson, P.P. Lowry II, J. Rabenantoandro, Z.S. Rogers, R. Rabevohitra \& D. Rabehevitra (2006). Deforestation and plant diversity of Madagascar's littoral forests. Conserv. Biol. 20: 1799-1803.

Gautier, L. (2003). Sapotaceae. In: Goodman, S.M. \& J.P. Benstead (ed.), The Natural History of Madagascar: 342-346. The University of Chicago Press.

Gautier, L. \& Y. Naciri (2018). Three critically endangered new species of Capurodendron (Sapotaceae) from Madagascar. Candollea 73: 121-129. DOI: https://dx.doi.org/10.15553/ c2018v731a13

Gautier, L., Y. Naciri, A.A. Anderberg, J.E.E. Smedermark, R. Randrianaivo \& U. Swenson (2013). A new species, genus and tribe of Sapotaceae, endemic to Madagascar. Taxon 62: 972-983. DOI: https://dx.doi.org/10.12705/625.17

Govaerts, R., D.G. Frodin \& T.D. Pennington (2001). World Checklist and Bibliography of Sapotaceae. Royal Botanic Gardens, Kew, UK.

Hassold, S., P.P. Lowry II, M.R. Bauert, A. Razafintsalama, L. Ramamonjisoa \& A. Widmer (2016). DNA barcoding of Malagasy Rosewoods: towards a molecular identification of
CITES-Listed Dalbergia species. PLoS One 11: e0157881. DOI: https://doi.org/10.1371/journal.pone.0157881

Humbert, H. (1955). Les territoires phytogéographiques de Madagascar. Leur cartographie. Année Biol. ser. 3, 31: 195-204.

IUCN (2012). IUCN Red List Categories and Criteria: Version 3.1. Ed. 2. IUCN Species Survival Commission, Gland \& Cambridge.

Labat, J.-N. \& O. Pascal (1997). Une nouvelle espèce de Labramia (Sapotaceae) de l'Ile de Mayotte dans l'Archipel des Comores. Adansonia ser. 3, 19: 213-216.

LAm, H.J. (1939). On the system of the Sapotaceae, with some remarks on taxonomical methods. Recueil Trav. Bot. Neerl. 36: 509-525.

Mackinder, B., D.J. Harris \& L. Gautier (2016). A reinstatement, recircumscription and revision of the genus Donella (Sapotaceae). Edinb. J. Bot. 73: 1-43.

Pennington, T.D. (1991). The genera of the Sapotaceae. Royal Botanic Gardens, Kew.

Swenson, U. \& A.A. Anderberg (2005). Phylogeny, character evolution, and classification of Sapotaceae (Ericales). Cladistics 21: 101-130. 